Makale Geliş | Received: 09.10.2018

Makale Kabul | Accepted: 18.10.2018

DOI: $10.18795 /$ gumusmaviatlas.468777

Mavi Atlas, 6(2)/2018: 217-245.

Araştırma Makalesi | Research Article

\author{
Şemsettin ÇELIKK \\ Dr. Öğr. Üyesi | Assist. Prof. Dr. \\ Bayburt Üniversitesi, İnsan ve Toplum Bilimleri Fakültesi, Tarih Bölümü, Bayburt, TR \\ Bayburt University, Faculty of Humanity and Social Sciences, Department of History, Bayburt, TR \\ ORCID: 0000-0002-8775-9647 \\ semseddincelik@hotmail.com
}

\title{
Erzurum İlmi Muhitine Bir Bakıș (On Dokuzuncu Yüzyıla Kadar) ${ }^{1}$
}

Öz

Bu çalışmada öteden beri Anadolu'nun doğusunda ilme ve kültüre merkezlik yapmış kadim bir şehir olan Erzurum'da XIX. yüzyıla kadar cereyan eden ilmi faaliyetler genel olarak ele alınmıştır. Özellikle Saltuklularla başlayan şehirdeki ilmi ve kültürel muhit, İlhanlılar tarafindan oldukça ileri seviyelere taşınmıştır. Bunlar tarafından kurulan Erzurum'daki ilmi ve kültürel müesseseler, sadece bulunduğu şehir için değil, aynı zamanda civar șehirlerin halkı için de hizmet vermiştir. XVI. yüzyılda devletlerarasındaki siyasi çatışmalardan Erzurum'daki ilmi muhit de epeyce yara almıştır. Bu yüzyılın sonlarına doğru yaralarını saran șehir, XVII. ve XVIII. yüzyılda ilmi, edebi ve kültürel bir muhit hüviyetine kavuşmuştur. Özellikle XVIII. yüzyılda Erzurum ilmi ve kültürel yönden kendi kendine yetebilecek seviyeye ulaşmıştır. Bu dönemde, Şeyhülislam Feyzullah Efendi, Müderris Hazık Mehmet Efendi ve Şeyh İbrahim Hakkı gibi şahsiyetler, Erzurum'da eğitim-öğretim görmüş, Osmanlı Devleti’nde söz sahibi olmuş ve yaşadıkları dönemde iz bırakmışlardır.

Anahtar Kelimeler: Erzurum, İlim, Kültür, Eğitim, Öğretim.

\section{An Overview of the Scientific Environment of Erzurum (Until the Nineteenth Century)}

\begin{abstract}
In this study, the scientific activities that took place until the XIX ${ }^{\text {th }}$ century in Erzurum, an ancient city, which has been centered on science and culture in the east of Anatolia, has been discussed in general. In particular, the scientific and cultural neighborhoods in the city, which started with the Saltuks, were moved to a very advanced level by the Ilkhanians. The scientific and cultural institutions in Erzurum, established by them, served not only for the city where it was located, but also for the people of the surrounding cities. From the political conflicts between the states in the XVI ${ }^{\text {th }}$ century, the scientific neighborhood in Erzurum has also suffered a lot. Towards the end of this century, the city that has covered its wounds has gained a scientific, literary and cultural identity in the XVII ${ }^{\text {th }}$ and XVIII ${ }^{\text {th }}$ centuries. Especially in the XVIII ${ }^{\text {th }}$ century, Erzurum reached its level of scientific and cultural selfsufficiency. In this period, such as Şeyhülislam Feyzullah Efendi, Müderris Hazık Mehmet Efendi and Şeyh İbrahim Hakkı had been educated in Erzurum, had a say in the Ottoman Empire and left their mark in the period they lived. In this period, such as Şeyhülislam Feyzullah Efendi, Müderris Hazık Mehmet Efendi and Şeyh İbrahim Hakkı received education in Erzurum, had a say in the Ottoman Empire and left their mark in the period they lived.
\end{abstract}

Keywords: Erzurum, Science, Culture, Education, Teaching.

${ }^{1}$ Bu makale, 2001 yılında Atatürk Üniversitesi Sosyal Bilimler Enstitüsü’nde kabul edilen "XIX. Yüzyılda Erzurum'da İlmi Muhit” adlı Yüksek Lisans tezinden üretilmiştir. 


\section{Giriş}

Birçok yönden öne çıkan Erzurum'un bulunduğu mevki onun önemini daha da artırmıştır. Mevki itibariyle ticaret, ilim ve kültür yollarının kavşağında bulunması Erzurum'u Anadolu'nun önde gelen ilim merkezlerinden biri haline getirmiştir. Bilhassa İslami devirde şehrin bu özelliği gözle görülür derecede artmıştır. Zira Müslüman Türklerin eline geçmeden önce Erzurum'u elinde bulunduran siyasi teşekküller, şehre askeri ve ticari bakımdan önem vermişler ancak şehrin ilmi ve kültürel ciheti ikinci planda kalmıştır. Bunda bölgede sık sık meydana gelen siyasi çekişmelerin de payı vardır. Aynı durum Müslüman Türklerin hâkimiyetinde de geçerli olmakla birlikte, Türk devletlerinin sahip olduğu din ve kültür birliği, Erzurum'da ilmi bir çevrenin oluşmasına zemin hazırlamıştır. Kısacası şehrin ilim ve kültür yönünden belirgin bir kimliğe kavuşması İslami devirde gerçekleşmiştir.

\section{Osmanlı Hâkimiyetine Kadar Erzurum'da İlmi Muhit}

Erzurum'un ilmi ve kültürel bakımdan kendini göstermesinin İslami devirde gerçekleştiğine yukarıda değinmiştik. İşte bu yolda, Erzurum'dan çıkmış olan ilk âlim Ebû Alî el-Kâlî’dir (Uylaş 2015: 7-9). Tam adı İsmail b. El-Kasım b. Azyûn b. Harûn b. İsâ b. Muhammed b. Süleyman el-Kâlî el-Bağdadî’dir (İbn Hallikan: 226). ${ }^{2}$ Ebû Alî elKâlî’nin ismindeki “Kâlî” kelimesi Erzurum’a mensubiyetini göstermekte olup, Araplar tarafından Erzurum'a verilen isim olan Kâlîkala’dan gelmektedir (Belâzûrî 1866: 197). ${ }^{3}$ Dedesinin adı Süleyman mı Selman mı olduğu konusunda ihtilaf vardır. Ebû Alî el-Kâlî ilim tahsili için 915(303)te Musul'a, 917(305)de Bağdat'a gitmiş ve oralarda büyük âlimlerden dersler almıştır. Daha sonra Endülüs’e göçen Kâlî, burada Arapça ve nahiv ilmi açısından yüksek bir dereceye ulaşmıştır. Kâlî, 967(356) yılında Kurtuba'da vefat etmiştir (Uylaş 2015: 9, 17, 27). Ebû Alî el-Kâlî’nin Erzurumlu olup olmadığı tartışma konusu $^{4}$ olsa da, o, Erzurum'un ilim ve kültür hayatında bir çığır açmıştır ve önemli olan da budur.

Erzurum'da ilmi muhitin inşa faaliyetleri Saltuklularla başlar. Bu bakımdan Anadolu'da kurulan ilk Türk beyliklerinden olan Saltuklular, şehirde ilmi ve kültürel sürekliliği başlatmışlardır. Erzurum'da kültürel ve ilmi sürekliliğin, XI. asrın ikinci yarısının ortalarından, yani 1080 yılından sonra Saltuklu Beyliği zamanında başladığını söylemek mümkündür. Saltuklu emirlerinin özel kütüphanelerinin bulunması, bunların

\footnotetext{
${ }^{2}$ El-Kali, Ebu Ali el-Bağdadî olarak da bilinir. (Yâkût el-Hamevî 1993: 729).

${ }^{3}$ Erzurum'un eski isimleri için bkz. (Küçükuğurlu ve Çelik 2013: 25-28).

${ }^{4} \mathrm{Bu}$ tartışma için bkz. (Uylaş 2015: 9-14).
} 
adına yazılan ve bugüne kadar kütüphanelerde saklı kalan bazı eserlerin varlığı bunu göstermektedir. Saltuklular, Erzurum'un ilim hayatına Ulu Cami, Kale Mescidi olarak da bilinen Melik Saltuk Gazi Cami ve Üç Kümbetler gibi eserlerle katkıda bulunmuşlardır (Sümer 1990: 43; Turan 1993: 34-35). Saltuklular şehirde bir de kütüphane kurmuşlardır. Hatta 1076'da yazılmış o yılların tıp bilgileri hakkında açıklamalar yapan Kitabül-Hiraye Fit-Tıbb adlı Farsça bir eserin de çevirisi yapılmıştır (Başar 1998: 11). ${ }^{5}$

Erzurum'da Saltuklulardan sonraki devre ait sadece ilmi muhitin bir parçasını oluşturan medreseler, bu devrin değerli mimari eserleridir. Bunlar Çifte Minareli, Ahmediye, Yakutiye ve Sultaniye medreseleridir. Bugün Tebriz Kapı semtinde Ulu Caminin doğusunda bulunan ve Hatuniye Medresesi olarak da bilinen Çifte Minareli Medrese'nin ne zaman ve kim tarafindan yaptırıldığı kesin bir şekilde belirlenememiştir. Araştırmacılardan bazıları medresenin, Anadolu Selçuklu Sultanı Alaeddin Keykubad'ın kızı Hundi Hatun tarafından 1253 yılında, bazıları da İlhanlı Hükümdarı Geyhatu'nun hanımı Hatun tarafından 1290 yılı civarında yaptırıldığını söylemektedirler. Ancak medresenin İlhanlılar devrine ait olduğu kuvvetle muhtemeldir (Karamağaralı 1971: 234-235). Lala Paşa Camisinin batısında bulunan Yakutiye Medresesi, 1310 yılında İlhanlılar zamanında Hoca Cemaleddin Yakut tarafindan yaptırılmıştır. Ahmediye Medresesi Erzincan Kapısı'ndaki Murat Paşa Camisinin yanındadır ve 1314-1324 tarihleri arasında Ahmed b. Ali b. Yusuf tarafından inşa ettirilmiştir (Konukçu 1992: 76). Erzurum'un en eski medreselerinden biri olan Sultaniye medresesi ise, Lala Paşa Camisi'nin doğusunda, eski belediye binasının batısında, Paşa Sarayı kapısının önündeydi. Bugün mevcut olmayan Sultaniye medresesinin yerinde, şimdi SGK binasının önünden geçen Menderes caddesi bulunmaktadır (Küçükuğurlu 2018: 123).

Bugünkü bulundukları mevki ve inşa tarihleri kısaca verilen bu medreseler İlhanlılar zamanına aittir ve hepsinin vakıfları mevcuttu. Medreselere devam eden talebelerin yemekleri vakfın varidatından karşılanıyor ve bu yolla fakir çocuklarının da okuması sağlanıyordu. Dolayısıyla bu medreseler, sadece Erzurum'un değil, civar memleket ahalisinin de ilim ve kültür merkezi olmuşlardır. Nitekim ünlü Mevlevi şeyhi Ulu Arif Çelebi, Erzurum'u ziyaret ettiğinde Yakutiye Medresesine misafir olmuş ve burada ağırlanmıştı. Bu da şehirdeki ilmi çevrenin İlhanlılar tarafından ne ölçüde desteklendiğini göstermektedir.

\footnotetext{
${ }^{5}$ Başar’a göre, bahsi geçen eser kütüphane ile birlikte Fatih Kütüphanesi’ne nakledilmiştir (Başar 1998: $11)$.
} 
Bu devirlerde Erzurum'da yetişmiş şair, yazar, mutasavvıf, müderris, şeyh gibi ilim adamları ve vücuda getirdikleri eserleri vardı. Ancak bunların büyük kısmı günümüze ulaşmamıştır. Bunun en esaslı sebebi Erzurum'un sınır şehri oluşu ve sürekli saldırılara maruz kalışıdır. Ayrıca Erzurum'un çeşitli devletlerarasında el değiştirmesi sonucu bu döneme ait eserler ya kaybolmuş veya bu dönemde Erzurum'da yetişmiş ilim adamları göç ederek gittikleri yerlerde eserlerini meydana getirmişlerdir. Bu bakımdan XIV. yüzyılın ikinci yarısında yaşamış şair ve yazar "Kadı Darir" yahut "Erzurumlu Darir” önemli bir örnektir (Karahan 1995: 2). Mustafa b. Yusuf b. Ömer el-Erzeni’rRumî (Köktekin 2015: 7-8) ${ }^{6}$ diye bilinen Erzurumlu Darir, doğuştan kör olduğu halde kuvvetli hafızası sayesinde İslami ilimleri öğrenmiş ve kadılığa kadar çıkmıştır. Şöhreti ve etkisi az zamanda Anadolu, Suriye ve Mısır'a yayılan Darir, 1377'de Mısır'a gitmiş ve Melik Mansur Ali’nin meclisine katılmıştır (Okçu ve Karabey 1989: 401). Onun yanında bulunduğu zaman Siyer-i Nebi adlı eserini 1388 tarihinde tamamlamış ve bu eserini Sultan Berkok bin Enes'e ithaf etmiştir. Daha sonra Halep'e gitmiş burada Halep naibi Emir Çolpan için Fütuhu'ş-Şam adlı eseri tercüme etmiştir (Köktekin 2015: 7). Darir, kendisinin ifadesine göre Erzurumludur ve Erzurum'da doğmuştur (Findıkoğlu 1927: 25, 29). Darir'in şöhrete ulaştıktan sonra memleketinden ayrılması, onun tahsilini Erzurum'da yaptığını göstermesi açısından önemlidir.

Darir'in, “Kıssa-i Yusuf, Siretü’n-Nebi, Fütûhu'ş-Şam, Yüz Hadis ve Yüz Hikâye" adında dört eseri mevcuttur. Bunların ilki telif, diğerleri ise tercümedir. Kadı Darir, şairliğinin yanı sıra daha çok nesir türü eserleriyle ün yapmıştı (Kasır 1999: 19). Kullandığı dil Eski Anadolu Türkçesidir (Köktekin 2015: 8). Darir'in hayatının sonlarında yazdığ 1 "Fütuhu'ş-Şam" adlı eserinde "Mevlevi" mahlasını kullanması, onun Mevleviliğe intisap ettiğine işaret sayılmaktadır (Erkan 1993: 498). Bu da Darir’in mutasavvıf kişiliğini gösterir. Ayrıca Siretü’n-Nebi ve Fütuhu'ş-Şam eserleri, Darir'in tarihçiliğine yorulmaktadır. Darir’in ölüm tarihi bilinmemekle beraber, 1393'den sonra vefat ettiği sanılmaktadır.

XIV. asırda Erzurum'da yetişen diğer önemli şahsiyetler; Ebu Abdurrahman, Mahmut Efendi, Hüseyin oğlu Mehmet, İmam Fahrettin Davut, Zahide Hatun, Ahi Tuman ve edebiyat ve lisan âlimlerinden Receb b. Karaca el-Erzen el-Rumi ile Sira alNabi’dir (Yınanç 1997: 353).

\footnotetext{
${ }^{6}$ Dedesinin adı Ömer, babasının adı Yusuf olan Kadı Darir, Kitabu Siretü'n-Nebi adlı eserinde kendisini Mustafa bin Yusuf bin Ömerü'd-Darirü’l-Erzeni’r-Rumî diye tanıtır. Bununla birlikte bazı kaynaklarda, Mustafa b. Yusuf b. Ömer, Mustafa Darir, Erzurumlu Kadı Darir, Erzurumlu Darir olarak da geçmektedir. Doğuştan kör olduğu için "anadan doğma kör" manasına gelen "Darir", bazı eserlerinde de "Gözsüz" mahlasını kullanmıştır (Köktekin 2015: 7-8).
} 
Bunlardan tam adı Ebu Abdurrahim Abdurrahman olan Ebu Abdurrahman, ilmiye sınıfından olup Mustafa isimli birinin oğludur. Kudüs'e giderek burada ders vermiştir. İbn Battuta, 1326'da Erzurum'a geldiğinde bu zat ile görüşmüştür. Mahmud Efendi ise, Ebu Said Han zamanında Erzurum'da yaşamış, Hatuniye Medresesinde görev yapmış ve fikha ait "Hidaye"yi telif etmiştir. Babasının adı Hacı Hüseyin'dir (Konukçu 1992: 77). ${ }^{7}$ Hüseyin oğlu Mehmet, ulemadan olup 1314(714) senelerinde Erzurum'da yaşamıştır. "Dürerü't-Tenzil ve Gurerü’t-Tevil” adlı tefsir kitabının müellifidir (Beygu 1936: 169). Fahrettin Davut ile Zahide Hatun'un Çifte Kardeşler diye bilinen mezarları bugün Kars Kapısı semtinde bulunmaktadır. Bunların karı koca oldukları sanılmaktadır. İmam Fahrettin'in Erzurum Kadısı olması muhtemeldir. Kadı İbrahim adlı birinin kızı olan Erzurum'un kadın âlimlerinden Zahide Hatun 1311 yılında vefat etmiştir (Konyal1 1960: 427-428; Başar 1972: 77-78; Beygu 1936: 170)).

Bu devir Erzurum'un kültür hayatında önemli yeri olan Ahi Tuman'a gelince, Ebu Said Han zamanında Erzurum'da yaşamış olan Ahi Tuman, İbn Battuta'yı evinde üç gün misafir etmiştir (İbn Battuta 2000: 418).

Yine bu devirde kurulan Çifte Minareli Medrese, Yakutiye ve Ahmediye medreseleri gibi büyük medreseler, ilmin vazgeçilmez unsuru olan kütüphaneler de kurulmuştur. Bu kütüphanelere, Selçuklu ve İlhanlılar hayli kitaplar vakfetmişlerdir. Ancak bunlardan pek azı günümüze kadar ulaşabilmiştir. Erzurum'un uğradığı istilalardan şehirdeki her şey gibi kütüphaneler dolayısıyla kitaplar da nasibini almıştır. Günümüze kadar ise, ancak birkaç kitabın listesi ulaşabilmiştir (Beygu 1936: 166-167). ${ }^{8}$ Diğer yandan bu husustaki en büyük kayıp, Rusların 1828 Harbinde götürdükleri çok sayıdaki el yazması eserlerdir ve bunların tam listesi de belirlenmiş değildir.

XIV. asır Erzurum ilim ve kültür hayatından bahsederken Yunus Emre'ye de değinmek gerekir. Zira her ne kadar Yunus Emre, Erzurum'da doğup büyümemiş ve Erzurum'da yaşamamış ise de, şair ve mutasavvıf kişiliği ile Erzurum ilim ve kültür hayatındaki yeri, ondan bahsetmeyi zorunlu kılıyor. Bu itibarla, Fındıkoğlu da “Erzurum Şairleri” adlı eserinde Yunus Emre'ye hususi bir mevki vermiştir. Yunus ve Taptuk Emre'nin makamları Erzurum'dadır. Hatta İbrahim Hakkı, bir müddet burada

\footnotetext{
${ }^{7}$ Abdurrahim Şerif Beygu, hicri 730 senesi zilkade ayının beșinci gecesi tamamlanan bu eserin 319 sahife ve her sahifenin 23 satırdan ibaret olduğunu ve İstanbul Millet Kütüphanesi’nde 2239 numarada kayitlı olduğunu yazmaktadır. Bahsedilen tarih miladi olarak da takriben 20 Ağustos 1330 yllına tekabül etmektedir (Beygu 1936: 135).

${ }^{8}$ A. Ş. Beygu, söz konusu kitapların bir listesini eserinde vermiş̧tir. Bkz. (Beygu 1936: 166-167).
} 
türbe beklemiş, onların ve kendisinin manevî nüfuzunun bölgede yayılmasında etkili olmuştur (Findıkoğlu 1927: 20). ${ }^{9}$

Söz konusu devirde Erzurum, Selçuklular ile Osmanlılar arasındaki emaretler devrini, yani fetret zamanını geçirdiğinden şehirdeki ilmi muhit hakkında daha teferruatlı bilgiye sahip olunamıyor. XV. yüzyıla baktığımızda bu durum kendini daha fazla hissettirmektedir. Nitekim 1403-1406 y1lları arasında Timur'un huzuruna giderken Erzurum'a da uğrayan İspanyol elçi Clavijo, eskiden zengin ve büyük bir şehir olan bu beldenin, nüfusunun pek de fazla olmadığını yazmaktadır (Ruy Gonzales de Clavijo 1928: 138-139; Klaviyo 1975: 78). Zira bu devir Erzurum'u ile ilgili ilmi ve kültürel bir malzemeye rastlanmadığı gibi, edebi, mutasavvıf ve şair bir şahsiyete de tesadüf edilemiyor. Bu da şehirdeki siyasi istikrarın olmayışının doğal bir sonucudur.

\section{Osmanlı Hâkimiyetinden XIX. Yüzyıla Kadar Erzurum'da İlmi Muhit}

XVI. asrın başlarında Osmanlı hâkimiyetine geçen Erzurum, AkkoyunluKarakoyunlu, Akkoyunlu-Safevi ve Safevi-Osmanlı rekabeti sırasında her bakımdan olduğu gibi, ilim ve kültür hayatı yönünden de epeyce yara almıştır. Gerek bu mücadeleler sırasında, gerekse Kızılbaş korkusundan dolayı Erzurum'da nüfus oldukça azalmış ve ahali daha emin yerlere göç etmek zorunda kalmıştır. Nitekim ilk Osmanlı yazım defterlerinde Erzurum'la alakalı olarak, "kızılbaş fetreti sırasında ahalisi perakende olmuştur” (Aydın 1970: 106) ifadeleri, söz konusu vaziyeti açıkça ortaya koymaktadır. Erzurum'un bu durumunda, Kanuni Sultan Süleyman zamanına kadar herhangi bir değişiklik olmamıştır. Kanuni zamanındaki imar, iskân ve iyileştirme faaliyetleri ile yeniden bir şehir hüviyetine kavuşan Erzurum, bu dönemden itibaren eski durumuna dönmeye ve hatta daha da ileriye gitmeye başlamıştır. Siyasi istikrarla birlikte Anadolu'nun büyük şehirleri arasına katılan Erzurum'da, yavaş yavaş nüfus artmaya, her türlü sosyal ve ekonomik altyapı yeniden düzenlenmeye başlamıştır. Yeni cami, medrese, gümrük binaları, kale duvarları, surları, çeşmeler vs. özel ve kamuya ait binalar inşa edilmiştir. Kanuni'nin emri ile terk edilmiş ve harap olan köylerde eskiden var olan bütün tekkeler tamir edilerek, olmayan yerlere ve tehlikeli derbentlere yenileri yapılmıştır. Tekkeler bu yerlerin şenlenmesinde yerleştirici ve birleştirici birer sosyal müessese olmuşlardır (Konyalı 1960: 66).

\footnotetext{
${ }^{9}$ Fındıkoğlu'na göre, Yunus Emre Batı Anadolu'da doğmuş, zamanının mutasavvıflarından irşat almış, Anadolu'yu köşe köşe dolaşmış, Erzurum'da kuvvetli bir irşat müessesesi vücuda getirmiş, Erzurum'da ölmüştür. Ancak bu bilgiler doğru değildir. (Fındıkoğlu 1927: 20).
} 
$\mathrm{Bu}$ faaliyetler sonucu siyasi ve sosyal bakımdan tam bir Osmanlı şehri hüviyetine bürünen Erzurum, Anadolu'nun doğu sınırında en büyük beylerbeylik haline geldi (Sertoğlu 1968: 79; Aydın 1998: 80-81). ${ }^{10}$ Bu haliyle Evliya Çelebi'nin çağına ulaşan Erzurum'un, Evliya Çelebi’yi, “sözün kısası ilim tahsil edilecek diyardır” (Evliya Çelebi 1314: 210) dedirtecek kadar ilim ve kültür hayatı cihetinden geliştiği görülmektedir. Erzurum gümrüğünde memurluk yapan Evliya Çelebi'nin anlattığına göre; Erzurum'da ilim yapmak için medreselerle, ihtisas derecesinde eğitimin verildiği darül-kurra ve darül-hadis gibi ilim yuvalarının yanı sıra, çocukların eğitim gördüğü 110 adet sıbyan mektebi bulunmaktadır. Bunların meşhurları Lala Paşa Mektebi ile Cafer Efendi Mektebidir (Evliya Çelebi 1314: 210). Burada bahsedilen sibyan mektepleri, cami ve mescitlerdir.

$\mathrm{Bu}$ dönemde Erzurum'da cami, mescit ve medreselerle birlikte eğitim faaliyetlerinin yürütüldüğü diğer kamu müesseseleri olarak tekke, zaviye ve çeşitli tarikatlara ait dergâhlardır. Söz konusu kuruluşların resmi bir hüviyetinin bulunduğu muhakkaktır. Zira yukarıda da belirtildiği gibi, Erzurum ve çevresindeki köylerde bizzat Padişahın emriyle harap olan tekkelerin onarılması, tekke bulunmayan yerlere yenilerinin yapılması, bunu ortaya koymaktadır. Ayrıca buralara mensup olanlar; tekke, zaviye ve dergâhlarda eğitimlerini sürdürürken, bir yandan da padişaha dua etmekte ve ondan yardım görmekteydiler. Arşiv belgelerinde, bunlardan "duâgûyan"11 diye bahsedilir. Bu durumu, "Erzurum eyaletinde bulunan bazı duâgûyana, eyaletin mal sandığından ödenen maaş ve tayinat bahalarını mübeyyin defter” açıç̧a ortaya koymaktadır (BOA, ML.MSF, V). Hülasa Erzurum'un ilim ve kültür hayatında tekke, zaviye ve dergâhların yerini göz ardı etmek mümkün değildir. Bunların faaliyetlerini sırf dini hayatla ilişkilendirmek doğru olmaz; çünkü sosyal hayatla da ilişkileri vardır. Belki bu ikinci yönleri, birincisinden daha önde gelmektedir. Bu tarikat ve cemaatlerin en mühim amacı, mensuplarını en iyi şekilde eğitmek ve onları topluma faydalı birer insan olarak yetiştirmektir. Bunu da birtakım tasavvufi ve ilmi bilgiler vererek gerçekleştirmeye çalışmışlardır. Bu da tasavvufun toplum hayatında mühim bir yerinin olduğunu gösterir. Fakat mutasavvıf denilen birçok kimse, yalnızca tasavvuf ile alakalı değildir. Bir tarikat şeyhi, aynı zamanda müderris, şair, hattat ve müftü de olabiliyor idi ki, ileride bunların örneği verilecektir.

\footnotetext{
${ }^{10}$ Mithat SERTOĞLU, “XVI. Yüzyılda Erzurum”, Belgelerle Türk Tarihi Dergisi, Sayı: 8, (Mayıs 1968), s. 79; Dündar AYDIN, Erzurum Beylerbeyliği ve Teşkilatı; Kuruluş ve Genişleme Devri (1535-1566), Ankara 1998, s. 80-81.

${ }^{11}$ Osmanlı devlet teşkilâtında ve tarikat hiyerarşisinde bir unvan. (İpşirli, 1994: 541).
} 
Erzurum'da Osmanlılardan önceki dönemlerde yapılan cami, mescit ve medreselerin büyük bir kısmı varlığını korurken, Osmanlı döneminde de şehirde epeyce cami, mescit ve medrese inşa edilmişti. Ali Paşa, Ayaz Paşa, Boyahane, Bakırcı, Caferiye, Cennetzade, Esat Paşa, Dervişağa, Gümrük, Gürcü Mehmet Paşa, Hacı Cuma, İbrahim Paşa, İhmal (Topçuoğlu), Kadana, Kasım Paşa, Kemhan, Köse Ömer Ağa, Kurşunlu=Feyziye (Şeyhülislam), Lala Mustafa Paşa, Mehdi Efendi (Sıvırcık), Murat Paşa, Narmanl1, Pervizoğlu, Salihiye, Şeyhler, Vani Efendi, Veysi Efendi, Yegenağa ve Zeynel Camisi bu dönem camilerindendir. Hacı Halil Ağa, Muid Efendi, Muveffekiye, Ayas Paşa, Kacıroğlu, Narmanlı, Feyziye, İslahiye, Muhammediye, Hacı Hamza, Şeyhler (Darüssafa), Hacı Ali Ağa medreseleri ise, XIX. yüzyıla kadar Erzurum'da bina edilen Osmanlı dönemi medreseleridir.

\section{Yüzyılda Erzurum'da İlmi Muhit}

Bu devirde Erzurum'un yetiştirmiş olduğu ilk ve en önemli edebi şahsiyetlerden birisi Şair Nef'i'dir. Asıl adı Ömer olan Nef'i, muhtemelen 1572 yılında, Erzurum'un Hasankale (Pasinler) ilçesinde doğmuştur. Dedesi Pasinler Sancak Beyi, Mirza Ali'dir. Babası hayatının son dönemlerinde Kırım Hanı'na nedimlik de yapmış, şair bir zat olan Mehmet Bey’dir (Karahan 1992: 1-2). Adı kaynaklarda, “Ömer Bey”, "Nef’i Ömer Efendi” şeklinde geçmektedir (Akkuş 2015: 5).

İlk tahsiline Hasankale'de başlayan Nef'i, medrese tahsilini Erzurum'da ikmal etmiştir (Fındıkoğlu 1927: 30). 1585-1588 yılları arasında Erzurum'da Defterdarlık yapan Gelibolulu Mustafa Ali, onun hocalığını yapmış ve şair kişiliğinin gelişmesinde önemli rol oynamıştır. Gençliğinde şiire merak salan Nef'i, şiirlerinde önce "Darri" (zarara ait, zararlı) mahlasını kullanırken, daha sonra hocası tarihçi Mustafa Ali'nin de etkisiyle Nef'i (faydalı, yararlı) mahlasını kullanmıştır (Mehmet Tahir 1333: 441-442; Karahan 1986: 7; Kasır 1999: 24; Akkuş 1991: 1-2). XVII. yüzyıl başlarında İstanbul'a gelmiş ve burada otuz yıl kadar kalmıştır. I. Ahmet, I. Mustafa, Genç Osman (II.) ve IV. Murat zamanlarını idrak eden şair, birçok devlet adamının ilgi ve hediyelerine mazhar olmuş, çeşitli devlet memurluklarında bulunmuştur. Özellikle IV. Murat'ın iltifatlarına mazhar olan şair, padişahın nedimliğini de yapmıştır. Nef'i, hicivde sınır tanımayan bir şairdir. O, babasından devletin en ileri gelenlerine varıncaya kadar herkesi hicvetmiştir. Fındıkoğlu, Nef'i'nin hiciv şairi olmasını, haşin bir yaratılışa ve bilhassa yaşadığı devrin şartlarına bağlayarak, "Nef'i beyhude yere hüccav olmamış, muhit ve zaman onu, bu vadiye sevketmiştir” der (Fındıkoğlu 1927: 35, 119). Bu bakımdan Nef'i, 
bildiğini açıkça söylemekten çekinmeyen bir şairdir. Bu hususiyeti de onu idama mahkûm etmiştir. ${ }^{12}$

Nef'i’nin Türkçe Divan, Farsça Divan ve Siham-ı Kaza (Kaza Okları) olmak üzere üç eseri mevcuttur. Ancak Nef'i’nin bizi ilgilendiren yanı eğitim hayatıdır. Tahsilini Erzurum'da tamamladığı belirtilen Nef'i, çok iyi Farsça ve Arapça bilmektedir. Gerek bu hususiyeti, gerekse kültürel birikimi onun iyi bir eğitim aldığını, dolayısıyla bu devir Erzurum'unun ilmi ve kültürel cihetinin kalitesini gösterir. Zira Nef'i'nin İstanbul'a gidişi ve saraya dâhil oluşunda, yetiştiği muhit olan Erzurum'da aldığı eğitimin rolü büyüktür. Zaten onun, saray tarafından tanınması da Erzurum'da gösterdiği şair kişiliği sayesinde mümkün olmuştur. Farsça Divanı'ndaki tasavvufi şiirlere bakılırsa, Nef'i'nin mutasavvıf kişiliğinden de söz etmek gerekir. Hatta Mehmet Nusret Efendi, şairin Mevlana hakkında yazdığı sitayişleri, onun Mevlevilik tarikatına mensup olduğuna yormaktadır (Mehmet Nusret 1338: 96).

Bu dönemde Erzurum'un yetiştirmiş olduğu ikinci şahsiyet; âlim, tarihçi ve şair olan Erzurumlu İbrahim Mülhemi'dir. XVI. yüzyılın sonlarında Erzurum'da doğdu (Woodhead 1994: 323). “Canbolatzade Hocası” ismiyle şöhret bulan Mülhemi'nin ası1 adı İbrahim'dir. Mülhemi, onun mahlasıdır (Fındıkoğlu 1927: 36-37). Ayrıca doğduğu yere nisbetle "Erzurûmî" şeklinde de zikredilir (Woodhead 1994: 324). Matematiğe kabiliyeti olup, XVII. yüzyılın başlarında Nef'i ile birlikte İstanbul'a giden (Fındıkoğlu 1927: 36-37) Mülhemi, Osmanlı tarihinin "şahnamecilik” bahsinde ad bırakmış ve IV. Murat'1n emri ile o devrin olaylarını yazmaya memur edilmiştir. 13 Ekim 1650'de İstanbul'da vefat etmiştir (Babinger 2000: 180; Necip Asım 1329: 498-499; Fındıkoğlu 1927: 36).

Mülhemi, şairliğinin yanı sıra tarihçi ve müderristir. Mülhemi’nin Nef’i ile birlikte İstanbul'a gelmesi, onun da Nef'i gibi eğitimini Erzurum'da aldığı sonucunu doğuruyor. Zira hiç eğitim almamış birinin o dönemde siyasiliği kadar kültürel ve ilmi merkez de olan İstanbul'a gelerek, padişahın şehnameciliğine kadar yükselmesi ve hatta devrinin müverrihleri arasında kendine yer edinmesi mümkün görünmüyor. Müverrihin eserleri arasında "Tarih-i Mülûk-i Rum u Efrenc" ve "Şahname fi Hakk-1 Sultan Murad1 Rabi" sayılabilir. Mehmet Tahir Bey, bir de divanının mevcudiyetinden bahsetmektedir (Mehmet Tahir 1342: 12-13). Ancak divanına bugüne kadar tesadüf

${ }^{12}$ Ey dil hele âlemde bir âdem yoğ imiş

Var ise de ehl-i dile mahrem yoğ imiş

Gam çekme hakikatte eğer arif isen

Farz eyle ki el'an yine âlem yoğ imiş 
edilememiştir. İbrahim Mülhemi, Arapça ve Farsça bilmekte olup; şiirlerini Türkçe, Arapça ve Farsça yazmıştır. Mülhemi'nin şairliğini göstermesi açısından şu misal yeterlidir.

Libâs-1 müsteâr olmaz muhabbet ehline lâyık

Kaba-yı atlas-1 çarha tenezzül mü eder âşık

Bu cisr-i mâsivâdan geçmeyince menzile ermez

Göze göstermek olmaz cûy-i eşki âşık-1 sâdık

XVI. yüzyılın sonlarında dünyaya gelen bir diğer Erzurumlu şahsiyet de şair Kâtibi'dir. Asıl adı Osman olan Kâtibi, 1595'te Erzurum'da doğmuştur. İyi bir öğrenim görmüş, ozan bir şairdir. Hayatı hakkında fazla malumat yoktur. Evliya Çelebi, onun yeniçeri kâtipliği yaptığını belirtir. Şairin Erzurumlu olduğunu vurguladığı bir şiiri şöyledir (Çelik 1997: 219-220):

Doğduğum yerleri görsem ölmeden

Çok gurbet dolaştım sıla görmeden

Bin dört tarihinde Erzurum'da ben

Âşıklar ilinde dünyaya geldim

Bu şiirinden anlaşıldığı kadarıyla Kâtibi, 1004 (1584) yılında doğmuştur.

XVII. yüzyılda, Erzurum'un yetiştirdiği diğer şahsiyetler arasında Osman Dede, Habib Muhammed Efendi, Muhammed Habib Efendi, Ebubekir el-İspirî, Hagob, Hattat Ömer, Hattat Halid Efendi, Cafer Efendi, Yeniçeri İmam ve Yeniçeri Müezzin bulunmaktadır. Genellikle tarihçiler arasında "Mühürdar Tarihi" adıyla anılan “Cevâhirü’t-Tevârih der Beyân-ı Menâkıb-1 Köprülüzâde Fazıl Ahmet Paşa” adlı eseri yazan Osman Dede, aslen Erzurumlu (Özcan 1994: 434) olup, Ali Efendi isminde birisinin oğludur. Söz konusu eserinde, Osman Dede, Fazıl Ahmet Paşa ve Girit Savaşından bahsetmekte, “...bende-i kemer beste-i etkıyâ Erzenü'r-Rûmî Osman Dede” ibaresiyle künyesini vermekte ve birçok yerleri dolaştıktan sonra Bursa'ya gelerek Fazıl Ahmed Paşa'nın hizmetine girdiğini yazmaktadır (Gülsoy 2000: 641). ${ }^{13}$

\footnotetext{
${ }^{13}$ Enver Konukçu, Franz Babinger’den nakille "Tarih-i Müluk-1 Rum Afranc", "Şahname-i Murad-1 Rabi" ve "Fetihname-i Kara Boğdan" gibi eserlerinde Osman Dede'ye ait olacağını yazmaktadır (Konukçu 1992: 222). Ancak yukarıda da yazdığımız gibi Mehmet Tahir Bey, bahsedilen eserlerin bir diğer Erzurumlu müverrih İbrahim Mülhemi'ye ait olduğunu belirtmektedir. Buradaki problemin, kişilerin birbirine karıştırılmasından yahut da eserlerin yanlış kişilere atfedilmesinden kaynaklandığını sanıyoruz. Zira Franz Babinger, "Osmanlı Tarih Yazarları ve Eserleri" adlı eserinde, Hasan Ağa'ya ait olarak verdiği "Mühürdar Tarihi"nin, Erzurumlu Osman Dede'ye aidiyetinin de iddia edilebileceğini yazmaktadır (Babinger 2000: 238). Gerçekte söz konusu eser, Mühürdar Hasan Ağa'nındır. Hasan Ağa eserini yazdıktan sonra, bunu münşiyâne bir üslupla yazması için Osman Dede'ye müsvedde olarak
} 
Habib Muhammed Efendi, Karabağ'da "Pir" namıla bilinen Nakşibendi şeyhlerinden Seyyid Muhammed Efendi'nin küçük oğludur (Mehmet Nusret 1338: 93). ${ }^{14}$ Doğum tarihi belli değildir. İran ahalisinin resmen şiiliği kabul etmesi ve ehl-i sünnete karşı giriştikleri katliam sırasında, ailesiyle birlikte İran'dan göç ederek Erzurum'a gelmiş ve burada yerleşmişlerdir. Habib Muhammed Efendi, Erzurum'da "Şeyhler" adıyla bilinen mahalleyi tesis ederek kendine mensup olanları buraya yerleştirmiş ve bu mahallede bir de kerpiçten mescit yaptırmıştır. Mehmet Nusret Efendi, "Erzurum'da ilmin mebde-i intişarının bu zattan başladığını" yazar. Ayrıca Mehmet Nusret'e göre, âlim ve fazıl bir zat olan bütün ömrünü tedris ile geçiren Habib Muhammed Efendi, 1620 (1030) tarihinde, Erzurum Müftüsü bulunmaktaydı. 1630 (1040) tarihinde vefat etmiş ve Köşk civarında ailesine ait kabristana defnolunmuştur (Mehmet Nusret 1338: 93-94). Ancak Çöğenli ve Kara’nın “Erzurum’un Yüzleri: Şeyhülislam Feyzullah Efendi” adlı eserlerinde, Habib Muhammed Efendi'nin 80 yaşlarında iken 1616 (1025) tarihinde öldüğünü ifade ederler. Buradaki bilgilerden kanaatimizce ikincisine yani Çöğenli ile Kara'nın vermiş olduğu bilgilere itibar etmek daha doğru olacaktır. Zira bu iki yazar vermiş oldukları bilgileri Habib Muhammed Efendi'nin torunu Feyzullah Efendi'nin bırakmış olduğu iki farklı eserden almışlardır (Çöğenli ve Kara 2015: 5, 8). Bu durumda Habib Muhammed Efendi, 1606 (1015) tarihlerinde Erzurum Müftüsü bulunuyordu.

Muhammed Habib Efendi, bahsi geçen Habib Muhammed Efendi'nin oğludur. Baba ve oğulun ikisi de aynı isimle adlandırılmış olup, ancak aradaki farkı göstermek için pederin mahlası önce, oğlununki ise sonra verilmiştir (Mehmet Nusret 1338: 94). Doğum tarihi tam olarak bilinmemekle beraber, 1609 (1018) olma ihtimali yüksektir (Çöğenli ve Kara 2015: 9). Muhammed Habib Efendi, babasının ölümü üzerine Erzurum Müftüsü yapılmış ve yirmi sene bu makamda bulunmuştur. Eğitimini babasından almıştır. Dolayısıyla tahsilinin tamamını Erzurum'da ikmal etmiştir (Mehmet Nusret 1338: 94). Meşhur Şeyhülislamlardan Feyzullah Efendi'nin babası (Çöğenli ve Kara 2015: 8) ve aynı zamanda hocasıdır. Dedesi Seyyid Pir Mehmet Efendi’nin menkıbe ve kerametlerini anlattı̆̆ı basılmamış bir eseri vardır. Bu eser, Birinci Büyük Harbe kadar Muhammed Habib Efendi’nin torunlarının kütüphanesinde

vermiş, Osman Dede de, bunu temize çekerek “Cevâhirü’t-Tevarih” adlı eseri vücuda getirmiştir (Gülsoy 2000: 641).

14 Mehmet Nusret, Habib Muhammed Efendi’yi Seyyid Muhammed Efendi'nin büyük oğlu olarak gösterse de, başka bir kaynakta Muhammed Efendi'nin iki oğlu olduğu ve büyük oğlunun Veliyyüttin Mehmet olduğu dolayısıyla Habib Mehmet Efendi’nin ise küçük oğlu olduğu yazmaktadır (Çöğenli ve Kara 2015: 8). 
muhafaza edilmekteydi (Mehmet Nusret 1338: 94). Muhammed Habib Efendi, 1693 (1104)de vefat etmiş ve aile kabristanında ağabeyi Şeyh Mustafa'nın yanına defnolunmuştur. Cenazesini bu siralar Erzurum'da bulunan Feyzullah Efendi kıldırmıştır (Çöğenli ve Kara 2015: 9). ${ }^{15}$

Hazık Mehmet Efendi'nin babası olan Ebubekir Efendi, Erzurum'un İspir ilçesinde doğmuştur (Mehmet Nusret 1338: 95; Okçu ve Karabey 1989: 407). Erzurum'da birçok âlimin hocalığını yapmıştır. İlim yolunda her türlü sıkıntıya katlanarak zor şartlar altında Karabağ'a kadar giderek burada Nesh-i Taliye ve Aliye’yi ikmal ettikten sonra Erzurum'a dönmüş ve Çifte Minareli (Hatuniye) Medreseye müderris olmuştur. $\mathrm{Bu}$ medresede otuz sene müderrislik yapmış ve birçok talebe yetiştirmiştir. Müderrisliği döneminde Erzurum'da ekser ulemanın icazetnamelerinde Ebubekir Efendi'nin adı kayıtlıdır. Ulema arasında "Karabekir Efendi" namıyla şöhret bulmuştur. Mehmet Nusret, 1713 (1125) tarihinde vefat eden Ebubekir Efendi'nin Erzincankapısı Mezarlığına defnolunduğunu ve mezar taşına vefat tarihinin yazılmadığını kaydetmektedir (Mehmet Nusret 1338: 95). Ancak Hüseyin Güfta “Erzurum’un Yüzleri: Hazık” adlı eserinde, Ebubekir Efendi'nin 1723 yılında öldüğünü ve Hazık Mehmet Efendi'nin de babasının vefatına tarih düştüğünü yazmaktadır (Güfta 2014: 3). Ebubekir Efendi, muhtelif ilimlerle ilgili on kadar eser kaleme almıştır. Oğulları tarafından muhafaza edilen bu eserler, 1828 yılında Rusların Erzurum'u istilası esnasında Erzurum'daki diğer kıymetli eserlerle birlikte gasp edilerek götürülmüştür (Mehmet Nusret 1338: 95).

Hayatı hakkında çok fazla bilgi olmayan Hagob, Ermenilerin Garin dediği Erzurum'da doğmuştur. XVII. yüzyılda yaşamış olan Hagob'un "Vekayiname” adlı eseri, Valarşapat'ta 1903'te yayınlanmıştır (Konukçu 1992: 222). Erzurum'da ilmi muhitten bahsederken konunun içine sadece Müslümanlar değil, aynı zamanda gayrimüslimler de girmektedir. Bundan dolayı Hagob'a da kısaca değinildi. Ancak Erzurumlu gayrimüslim âlimler hakkında hemen hiçbir bilgi yoktur.

XVII. yüzyılda, hat sanatının Erzurum'daki en önemli temsilcisi Hattat Ömer Çelebi'dir. Yazı sahasında şöhret kazanan Hattat Ömer Çelebi'den, Evliya Çelebi de sitayişle bahseder (Evliya Çelebi 1314: 215). Hattat Ömer Çelebi, Şeyhülislam Feyzullah Efendi'nin hat hocalığını yapmıștır. Feyzullah Efendi, Erzurum'da sürgünde bulunduğu siralarda hattat Ömer Çelebi vefat etmiş ve cenazesini talebesi Feyzullah

15 Muhammed Habib Efendi'nin ölüm tarihini Mehmet Nusret, 1689 (1100) olarak vermiştir. Ancak yukarda da belirtildiği gibi Sadi Çöğenli ve Ömer Kara'nın vermiş oldukları tarihi kabul etmek daha isabetlidir. (Mehmet Nusret 1338: 94). 
Efendi kıldırmıştır (Çöğenli ve Kara 2015: 26, 41). Ölüm tarihi tam olarak bilinmemekle beraber, Şeyhülislam Feyzullah Efendi 1688-1695 tarihleri arasında Erzurum'da sürgünde bulunduğu zaman vefat ettiğine göre, hattat Ömer Çelebi’nin ölüm tarihi bu aradadır.

Bu dönemde yetişmiş bir diğer şahsiyet de Erzurumlu hattat Halid Efendi'dir. Doğum tarihi ve hayatı hakkında yeterli bilgi yoktur. Erzurumlu olan ve Erzurum'da doğan Halid, İsmail Efendi'nin oğludur. Erzurum'dan İstanbul'a giderek devrin büyük hattatı Hasan Üsküdarî’den altı yazı çeşidini meşk edip icazet almıştır. Bu eğitimi onu zamanının büyük hattatlarından biri yapmıştır. Birçok hattat da yetiştiren Halid Efendi, yazı türlerindeki marifetinden başka, Arapça ibarelere olan vukufiyetiyle de dikkatleri çekmiştir. Eserleri içerisinde yer alan 1617 ve 1619 tarihli iki mushafi, Türk ve İslam Eserleri Müzesinde sergilenmektedir (Özdem 2015: 7-18). İstanbul'a ne zaman gittiği bilinmemekle birlikte, hocası Hasan Üsküdarî 1614 yılında vefat ettiğine ve Halid Efendi ondan altı yazı çeşidini meşk edecek kadar bir eğitim aldığına göre, hocasının ölüm tarihi olan 1614'ten çok önce İstanbul'a gitmiş olması icap eder. Dolayısıyla doğum yeri olan Erzurum'da, ilk hattatlık eğitimini almış olması ve sanatında belli bir dereceye ulaşması kuvvetle muhtemeldir. Zira hiçbir hat eğitimi almadan İstanbul'a gelip Hasan Üsküdarî’den ders almak mümkün görünmüyor. Gerek Halid Efendi gerekse ondan sonra gelen Ömer Çelebi, 16. yüzyılın sonlarından itibaren Erzurum'da hat sanatı üzerinde iyi bir muhitin varlığını göstermektedir.

Cafer Efendi, Evliya Çelebi'nin bahsettiğine göre, bir yandan beylerbeyi sarayında sohbetlerde bulunabilecek kadar bilgili, diğer taraftan da beylerbeyi ve maiyetine, kendine ait olan köyünde ziyafet verebilecek kadar zengin bir kimsedir (Evliya Çelebi 1314: 217, 220). ${ }^{16}$ Babası Ebubekir Efendi'dir. Cafer Efendi kendi adiyla anılan bir cami ve medrese inşa ettirmiştir. Cafer Efendi, Cami kitabesinde "mukataa-1 hazine-i Arz-1 Rûm", vakfiyesinde ise "mukataacı” olarak tanıtılmaktadır (Konyalı 1960: 198) ${ }^{17}$

$\mathrm{Bu}$ devirde Erzurum'da, hafiz-1 kurra olan ve sohbetleriyle cemaati mest eden Yeniçeri İmam ve Erzurum'un Küçük Bilal-i Habeşi'si sayılan, ezan okumakta mahir,

16 Cafer Efendi’nin görevi, cami kitabesinde “mukataa-i hazine-i Arz-1 Rûm”, vakfiyesinde ise "mukataacı" olarak belirtilmiştir. Erzurum Vilayeti’ne ait XVII. yüzyılda yapılan tahrirlerin Cafer Efendi tarafından yapılması da bunun bir delilidir (Kılıç 2009: 174).

171643 (1053) tarihli arşiv kayıtlarında da Cafer Efendi, Erzurum hazinesinde mukataacı, cizye mukataacısı ve muharrir olarak geçmektedir (BOA, MAD. d. 4277; BOA, MAD. d. 2929; BOA, MAD. d. 6422). Yine aynı tarihli bir başka arşiv kaydında ise Erzurum Eyaletinin cizye ve avarız muharriri olarak nitelendirilmektedir (BOA, MAD. m. 299). 
sesini duyan Erzurumlu'ya işini gücünü bıraktırıp camiye koşturan Yeniçeri Müezzin kayda değer şahsiyetlerdir. Yine Evliya Çelebi'nin çağında, Erzurum'da yaşayan bir diğer önemli şahsiyet de; âlim, müfessir, muhaddis kişiliği ile namı cihanı tutmuş; vaazını dinleyenlerin tövbekâr olduğu kürsü şeyhi Vani Efendi'dir (Evliya Çelebi 1314: 211).

\section{Yüzyılda Erzurum'da İlmi Muhit}

XVIII. yüzy1lda hükümet merkezindeki saray ve havas zümreleri gibi, büyük vilayet merkezlerinde de küçük zümreler teşekkül etmiştir. O kadar ki, artık bu dönemde beliren zekâların İstanbul'a gitmelerine gerek kalmamıştır. Çünkü ortaya çıkan bu şahsiyetlerin, ilmi ve edebi ihtiyaçlarını karşılayacak ve teşvik edecek muhitler, bulundukları şehirlerde teessüs etmiştir. Bu hususiyet XVIII. yüzyılda Erzurum'da da görülmektedir. “Küçük bir saray ve onun Paşa'dan, Vezir'den, Molla'dan ..." ibaret şahsiyetleri, aynı zamanda o sarayın ve şahsiyetler zümresinin ilmi ve edebi ihtiyaçlarını karşılayan şahsiyetler mevcuttur (Fındıkoğlu 1927: 120). Erzurum da XVIII. yüzyılda, kültürel ve ilmi yönden geçen asırlara göre daha çok gelişme göstermiştir. Osmanlı Devletinde söz sahibi olmuş şahsiyetler Erzurum'dan çıkmış ve yaşadıkları dönemde iz bırakmışlardır. Şeyhülislam Feyzullah Efendi, Hazık Mehmet Efendi ve Şeyh İbrahim Hakkı bunların başında gelmektedir.

Sözü edilenler arasında en önemli kişi Erzurumlu meşhur Şeyhülislam Feyzullah Efendi'dir. Şems-i Tebrizi sulbünden geldiği söylenen Erzurum Müftüsü Seyyid Muhammed b. Muhammed Efendi'nin oğlu olup, 1639 yılında Erzurum'da doğmuştur (Köprülü 1997: 593). Küçüklüğünden itibaren tasavvufi bir terbiyeden geçen Feyzullah Efendi, hayatının yaklaşık otuz yılını Erzurum'da geçirmiştir. İlk tahsilini babasından almıştır. Daha sonra Seyyid Abdulmümin Efendi, dayızadesi İsmail b. Murtaza ve o sıralar Erzurum yöresinin seçkin âlimlerinden olan Şeyh Muhammed Vani Efendi'den dersler almıştır. Hadis ilmini ise Muhammed Zahir ibn Abdullah al-Mağribî'den okumuştur. Hat dersini de bahsi geçen hattat Ömer Efendi'den almıştır (Çöğenli ve Kara 2015: 21, 26-27). Feyzullah Efendi, 1664'te o sıralar önemli bir mevki sahibi olan Vani Mehmet Efendi'nin çağrısı üzerine İstanbul'a gitmiştir. Vani Efendi'ye damat olan Feyzullah Efendi, bir süre sonra II. Mustafa'nın hocalığına getirilmiş ve sırasıyla Haydar Paşa, Mihrimah, Ayasofya Medreselerine, Süleymaniye Darülhadisine ve Sultan Ahmet Medresesine müderris olmuştur. III. Ahmet'in hocalığını da yapan Feyzullah Efendi, nakibü'l eşraflık ve şeyhülislamlık mevkilerine kadar ulaşmıştır. O böylece hem padişah hocası hem de şeyhülislamlık sıfatlarını üzerinde toplayarak "câmiür- 
riyâseteyn” unvanını alan ikinci şeyhülislam olmuştur (Köprülü 1997: 593, 598). 1688'de 20 gün süren şeyhülislamlıktan (Uzunçarşılı 1988: 225) azli üzerine memleketi Erzurum'a gelerek Şeyhler Mahallesindeki konaklarında ikamet ve yine tedrise devam etmiştir (Mehmet Nusret 1338: 98). Memleketinde yedi y1l kalan Feyzullah Efendi, kendisini tamamen eğitim, yazı ve eser tetkikine vermiştir. $O$ hem ailesi hem de mal ve mülkü ile kitaplarını da Erzurum'a getirtmişti (Konukçu 1992: 219; Konukçu 1989: 77). Erzurum'da kaldığı müddet zarfında Beyzavi Tefsiri'ni ve Sahih-i Buhari’yi okutmuştur.

Feyzullah Efendi, II. Mustafa'nın tahta çıkması üzerine İstanbul'a çağrılmış ve 1695 yılında tekrar şeyhülislamlığa getirilmiştir (Yıldırım ve Kılıç 2018: 624). ${ }^{18} \mathrm{Bu}$ ikinci şeyhülislamlığı aralıksız sekiz yılı aşkın sürmüş ve 1703 Edirne Vakasından dolayı katledilmiştir. Kaynaklar onun çok zeki ve süratle neticeye varma konusunda yegâne olduğunu zikreder (Köprülü 1997: 599; Konukçu 1992: 242). Fakat Uzunçarş1l1, bu meziyetlerine rağmen Feyzullah Efendi’nin, şeyhülislamlığı döneminde sergilemiş olduğu sınırsız ihtirası ve gadri yüzünden her sınıfın düşmanlığını kazandığından bahseder (Uzunçarşı1l 1988: 225). ${ }^{19}$ Eserleri: "Hâşiye alâ Envar et-Tenzil ve Esrâr etTe’vil”, “Asem Hâşiyesi”, "Nesayihü'l-Mülûk”; “Şerh-i Akaid”, “Kitâbü’l-Ezkâr”, "Mecmu’a-1 Hikâyet”, "Fetavâ-yı Feyziyye” ve "Ravza Tercümesi” dir (Çöğenli ve Kara 2015: 61-69; Tayşi 1994: 527). ${ }^{20}$ Feyzullah Efendi, bırakmış olduğu diğer eserleri ise, ilim yuvalarıdır. Erzurum'da Feyziye (Kurşunlu) cami ve medresesi ile darülkurra, Şam'da bir darülhadis, Mekke'de 1700 yılında inşa edilen bir Medresetü'ş-Şifa, Medine'de medrese, kütüphane, muallimhane, Edirne'de bir çeşme, İstanbul'da Feyzullah Efendi Medresesi ve kütüphane bunlardandır (Özcan 2013: 28). O, böylece yaşadığı devre damgasını vurduğu gibi, bırakmış olduğu eserleri ile de günümüzde dahi kendisinden söz ettirmektedir. Feyzullah Efendi'nin dönemi Erzurum'daki ilmi ve kültürel muhitin eriştiği yüksek mertebeyi göstermesi açısından önemlidir.

Bu dönemde Erzurum'da iz birakan ulema ve şuaradan biri de Hazık Mehmet Efendi'dir. Asıl adı Mehmet olan Hazık Efendi, "Karabekir" lakabıyla anılan ve

\footnotetext{
${ }^{18}$ Şeyhülislam Feyzullah Efendi, Sultan II. Mustafa'nın hocasıdır (Yıldırım ve Kılıç 2018: 624).

${ }^{19}$ Uzunçarşlı'ya göre, ilmiye işlerini kendi arzu ettiği gibi yürütmesi, oğullarını ve akrabalarını kayırması ve vezir-i âzamları etkisi altına alarak devlet işlerine el atması yüzünden şeyhülislamlığı döneminde artık Padişahın emriyle kendisine sorulmadan hiçbir iş yürümez hale gelmişti. Bu hallerinden dolayı kendisine karşı biriken kin, linç edilmesiyle sonuçlanmıştı (Uzunçarşılı 1988: 225; Uzunçarşılı 1995: 15-16, 22, 2930, 38-39).

${ }^{20}$ Feyzullah Efendi'nin İstanbul'da, Fatih'te yaptırdığı medrese, bugün Millet Kütüphanesi adını taşımaktadır. Erzurum'daki kendi adıyla maruf cami ve medresesi ise bugünkü Kurşunlu Cami'dir (Çöğenli ve Kara 2015: 61-69; Tayşi 1994: 527).
} 
Karabağ civarından geldiği söylenen Erzurum'un meşhur âlimlerinden İspirli Ebubekir Efendi'nin oğludur (Bilmen 1327: 1929). 1690 yılında Erzurum'da dünyaya gelen Hazık, ilk tahsilini babasından, daha sonra İhlasiye Medresesi müderrisi Müftü Ömer Efendi ve Kazabadi Ahmet Efendi gibi devrinin tanınmış âlimlerinden ders aldı (Güfta 1992: 4). Feyziye Medresesi müderrisi ve aynı zamanda babası İspirli Ebubekir Efendi' den ders alarak tahsilini tamamlamıştır (Çınarcı 2007: 40). Tahsilini Erzurum'da ikmal ettikten sonra yine burada İbrahim Paşa Medresesi ve bugün Çifte Minareli Medrese olarak bilinen Hatuniye Medresesinde müderrislik yaparak birçok talebe yetiştirdi (Güfta 2014: 4). Bunlardan birisi de “Marifetnâme” müellifi Şeyh İbrahim Hakkı'dır. Bilhassa Hatuniye Medresesi müderrisliği uzun süreli olanıdır. İyi bir eğitim almış olan Hazık; Türkçenin yanında Arapça ve Farsçayı da iyi derecede bilir ve yazardı. Devrinde yapılan bazı cami ve çeşmelerin manzum kitabelerini de yazmıştır ki Zeynel Camisi bunlardandır (Konyalı 1960: 433). Yine Erzurum'da Gül Ahmet Ağa tarafından Kars Kapısı civarında yaptırılan çeşmeye söylediği "Gel Gül Ahmet çeşmesinden gül âb âsâ suyu” tarihi manzum kitabesi meşhurdur (Mehmet Tahir 1333: 280-281).

Hz. Muhammed'in soyundan geldiği söylenen Hazık Mehmet Efendi, Erzurum Nakibü’l-Eşraflığına ve sonra 1756 yılında da Erzurum Müftülüğüne tayin olundu (Bilmen 1327: 1929). Ömrünün sonuna kadar bu görevi sürdüren Hazık, ilimle haşır neşir olmuş ve pek çok öğrenci yetiştirmiştir. Talebelerinden olan Erzurumlu İbrahim Hakkı'nın Farsça hocalığını da yapmıştır (Mehmet Tahir 1333: 280-281). Bir ara Hazık Efendi İstanbul'a gitmiştir, ancak nedeni bilinmemektedir.

Hazık, bir taraftan ilmi ve idari vazifesini yerine getirirken, diğer yandan da devrin ve şehrin edebi muhitinde mümessil tanınmıştır. İlmi ve edebi yönü ağır basan şairin tasavvufi cihetinin olduğu da şu şiirinden anlaşılıyor (Fındıkoğlu 1927: 46):

Aks-1 rah yar içün hayli nazar eyledim

Kendimi gördüm yine suret-i aynada

Böylece ilmi, edebi ve tasavvufi kişiliği ile XVIII. yüzyıl Erzurum'unun ilmi ve kültürel hayatında geniş akisler bırakan Hazık Mehmet Efendi, Nisan 1763’te, Erzurum'da vefat etmiş ve Erzincankapı Mezarlığına defnedilmiştir. Daha sonra mezarı buradan başka bir yere taşınmıştır (Güfta 2014: 5-6). Talebelerinden Şeyh İbrahim Hakk1, şu manzum tarihi beyitle vefat tarihini tespit etmiştir (Mehmet Nusret 1338: 104):

Hazık Efendi ilim ercümendi. 


\begin{abstract}
Allame kendi âlem beğendi
Hak rahmet itsün ruhuna gitsün

Cennetde tatsın bin şehd ü kandî

Hakkı denildi fevtine tarih

Hakka yöneldi Hazık Efendi
\end{abstract}

Hazık'ın vefatına tarih düşenlerden biri de Erzurumlu Zihnî’dir. Hatta, Zihnî bir değil, iki tarih birden düşmüştür. Zihnî’nin düştüğü tarihler şöyledir (Macit 1996: 5657):

Çıkdı biri vefâtını bî-nokta harf ile

Zihnî dedi hulûs ile zeyl-i sütûra bak

Geldi bir hâtif-i kudsî dedi Zihnî târih

Menzil-i Hâzık Efendi ola cây-1 vâlâ

Kaynaklara göre Hazık'ın üç eseri vardır. Bunlar; Kadı Beyzavi Tefsiri’ni açıklayan “Ta’likat 'ala Tefsiri'l-Beyzavi”, Erzurum Müftülüğü görevindeyken muhtelif konular hakkında verdiği "Fetvalar” ve en önemlisi Türkçe "Divan”dır (Bilmen 1327: 1930; Güfta 2014: 34-35). ${ }^{21}$ Neticede Hazık, eğitim ve öğretimini, Erzurum'da aldı̆̆ gibi, eserlerini de burada vücuda getirmiş ve yine bu şehirdeki medreselerde dersler vererek öğrencilerini de bu muhitte yetiştirmiştir.

Bu dönemde yetişmiş bir diğer Erzurumlu şahsiyet, "Marifetnâme" adlı eserin yazarı, ilim adamı, şair ve mutasavvıf Şeyh İbrahim Hakkı'dır. 1703 yılında, Erzurum'un Pasinler (Hasankale) kazasında doğmuştur (Fatin Davud 2017: 91). Şiirlerinden birinde kendi doğumunu şu mısralarla anlatmaktadır (Fındıkoğlu 1927: 47):

Hicretin tarihi bin yüz on beş oldu bahar

Kal'a-i Ahsen'de İbrahim Hakkı doğdu zâr

Babası Derviş Osman Efendi; annesi Şerife Hanife Hanım'dır. Henüz dört yaşında iken Kur'an-1 Kerim öğrenmeye başlamıştır. İlk eğitimini imam olan babasından ve Hasankaleli hocalardan almıştır. Sonra babasının Erzurum'a taşınması üzerine eğitimine burada devam etmiş ve Sarı Gümrükçü Derviş Efendi'den özel dersler alarak bilgisini artırmıştır. Mutasavvıf olan babası Derviş Osman Efendi'nin, bir mürşidi kâmil aramak arzusuyla çıktığı yolculukta söz konusu mürşidi (Şeyh İsmail Fakirullah), Siirt'in Tillo kasabasında bulup ona intisap etmesiyle İbrahim Hakkı için de

${ }^{21}$ Söz konusu divan, 1900 yııında Erzurum Nakibü'l-Eşrafı ulemadan Abdürrezzak İlmi Efendi tarafından İstanbul'da basılmıştır. (Bilmen 1327: 1930). 
yeni bir dönem başlamış olur. Çünkü daha sonra İbrahim Hakkı, amcası tarafından buraya getirilmiş ve eğitimini burada devam ettirmiştir. Aynı zamanda kendisi de Şeyh İsmail Fakirullah'a mürid olmuştur. İbrahim Hakkı, bizzat şeyhiyle ilk karşılaşmasını anlatırken, "şeyhin yüzü bana babamdan daha biliş ve tanış geldi" (İbrahimhakkıŏlu 1998: 21) der. Bir yandan eğitimini devam ettirirken diğer taraftan tasavvufi terbiye alır. Bu arada babasını kaybeden İbrahim Hakkı, Erzurum'a dönmüş ve Erzurum Müftüsü Hazık Mehmet Efendi'den Farsça dersler almıştır (Mehmet Tahir 1333: 33-34). 1747 yılında İstanbul'a giden İbrahim Hakk1, I. Mahmud'un özel izni ile Kütüphane-i Hümayun'dan faydalanma imkânı bulmuştur (Konukçu 1992: 243-244; Kasır 1999: 4748). 1753 yılında tekrar Erzurum'a geri dönmüş ve padişah tarafından Abdurrahman Gazi Vakfı Zaviyedarlığına atanmıştır. Bir süre Habib Efendi Camisinde imamlık yapmıştır. Bundan iki yıl sonra bir İstanbul seferi daha yapan Şeyh İbrahim Hakkı, dönüşünde eserlerini yazmaya başlamıştır (Altıntaş 1997: 23). En önemli eseri olan “Marifetname”yi, İstanbul dönüşü 1757'de Hasankale'de tamamlamıştır (İbrahimhakkıoğlu 1998: 23; Kırkkılıç 2015: 19). ${ }^{22}$

İbrahim Hakkı, 1780 yılının 22 Haziran günü Tillo'da vefat etmiş ve şeyhinin yanına defnedilmiştir. İbrahim Hakkı'nın vefatına Erzurumlu Zihni, şu tarihi düşmüştür (Macit 1996: 15):

Elimden aldı o meh ihtiyâr ile şabrım

Egerçi fikhda vardır mesâ'îl-i ikrâh

Hitâma irdi sühan başla dûrdan Zihnî

Dû'â-yı devlet-i eyyâma rûz u şeb her gâh

\footnotetext{
${ }^{22}$ İbrahim Hakkı'nın İstanbul seyahatine dair halk arasında bir de menkıbe anlatılır. Bu menkıbeye göre, İbrahim Hakk1, Erzurum'da etrafina müritler toplayarak isyana hazırlandığı gerekçesiyle devrin padişahına şikâyet edilir. Bu şikâyet üzerine devrin padişahı İbrahim Hakkı'yı İstanbul'a çağırır. İbrahim Hakkı, İstanbul'a gider ve padişah tarafından huzura kabul edilir. Ancak padişah, onu ayakta mı yoksa oturduğu yerde mi karşılayacağı hususunda tereddüde düşer ve çare olarak namaza durur ve böylece bu işin içinden çıkmak ister. İbrahim Hakkı, huzura girince padişahın namaz kıldığını görmesine rağmen padişaha selam verir. Padişah, "hah şimdi yakaladım" der. Namazı bitirince İbrahim Hakkı'ya dönerek "namaz kılana selam verilir mi" diye sorar. Bunun üzerine İbrahim Hakkı, "siz namazda değildiniz, sarayın duvarlarını hangi renge boyatacağınızla meşguldünüz" der. Bunun üzerine padişah İbrahim Hakkı'nın değerini anlar ve aralarında koyu bir sohbet başlar. Sohbetin sonunda padişah, İbrahim Hakkı'ya, "zamanın kutbu kimdir?" diye bir soru sorması üzerine, İbrahim Hakkı şu cevabı verir: "Hak bilir Hakkı'dır. Hakkı da Hakkı'dır" der ve padişahın huzurundan ayrılır. Padişah, o gittikten sonra, İbrahim Hakkı'nın verdiği bu cevapta zamanın kutbu olarak kendini kastettiğini fark eder. Bu menkıbeden dolayı İbrahim Hakkı, halk arasında "zamanının kutbu" olarak bilinir. Emekli İmam Hacı Selahattin Hoca (Çelik)den derlenmiştir. Baba adı: Yusuf, Ana adı: Mihriban, Doğum yeri ve tarihini: Erzurum/Narman - 1933, Derleme tarihini: 22.02.2017.
} 
Seni huzûr ile üns üzre şâd ede Mevlâ

Niteki devr ede tâk-1 felekde mihr ile mâh

Karîn-i devlet-i feyz eyleye selâmet ile

Bisât-1 hâki müzeyyen edince berg-i giyâh

İbrahim Hakkı, çok yönlü bir ilim adamı, mutasavvıf ve şairdir. Arapça ve Farsçayı, şiir yazacak kadar iyi bilirdi. Pek çok ilim dalında bilgisi vardı. O sadece mutasavvıf bir şair değil, akli ve şer'i ilimlerin hemen hepsiyle uğraşmış biridir. İbrahim Hakkı'nın bu seviyeye ulaşmasında kuvvetli zekâsının yanı sıra, iki muhitin etkisi bahis konusudur. Bu muhitlerden biri Erzurum, diğeri ise şeyhinin mekânı olan Tillo'dur. Hakkı, temelde üç kişilik gösteriyor. Bunlar; ilmî, edebî ve tasavvufî kişiliklerdir. Bunlardan ilk ikisini doğup büyüdüğü yer olan Erzurum'da aldı̆̆ ortadadır. Zaten yukarıda eğitiminin önemli bir kısmını bu muhitte aldığı belirtilmişti (Mehmet Tahir 1333: 33-34). ${ }^{23}$ Başlangıcı babasından olan mutasavvıf kişiliğini de Tillo'daki şeyhi İsmail Fakirullah’dan almıştır.

İbrahim Hakkı'nın kırka yakın eseri vardır. Marifetname'den anlaşıldığ kadarıyla o, bunların beşini "ana eser", diğerlerini de "evlad eserler” olarak nitelendirir. En önemli eserlerinin "Marifetname” ile Türkçe "Divan”" olduğunda şüphe yoktur. Ana eserler içerisinde zikredilen diğer eserleri ise, "İrfaniye”, “İnsaniye” ve "Mecmu’âtü’lMe’ânî”dir (İbrahimhakkıoğlu 1998: 36-37). İbrahim Hakkı, Anadolu'nun birçok yerinde bilinmektedir. Çünkü o, bir halk adamıdır. Tasavvufu da böyle anlamış ve anlatmıştır. Bu sebeple bugün bile halkın dilinden düşmeyen şiirleri vardır:

Hak şerleri hayr eyler

Zannetme ki gayr eyler

Ârif anı seyr eyler

Mevlâ görelim neyler

Neylerse güzel eyler

Deme şu niçin şöyle

Yerindedir ol öyle

Bak sonuna seyr eyle

Mevlâ görelim neyler

Neylerse güzel eyler

\footnotetext{
${ }^{23}$ Diğer taraftan Osmanlı Müellifleri’nin yazarı Bursalı Mehmet Tahir Bey de, bu konuya işaret ederek, İbrahim Hakkı'nın, “âlet ilimlerini ve yüksek ilimleri Erzurum âlimlerinden öğrendiği”ni söylemektedir (Mehmet Tahir 1333: 33-34).
} 
XVIII. yüzyılın bir diğer siması da asıl adı Mustafa olan Erzurumlu Zihnî’dir. Doğum tarihi belli değildir. Divanı'nın ketebe kaydında geçen “Zihnî-i Erzurumî” ifadesinden Zihni'nin Erzurumlu olduğu anlaşılmaktadır (Macit 2015: 2-3). Zihnî’nin tahsil hayatı ve mesleği hakkında bilgi sahibi değiliz. Fakat şiirlerine bakılırsa iyi bir medrese eğitimi gördüğünü söylemek mümkündür.

Zihnî’nin ne zaman öldüğü de bilinmemektedir. Ancak divanının 1212 (1797) yılında istinsah edilen nüshasında "el merhum, rahmetullahi aleyh" ifadelerine bakılırsa, şairin bu tarihte hayatta olmadığı anlaşılıyor. Hacı Mustafa Ăga'nın 1209 (1794-95) yılında yaptırdığı Kağdariç Köprüsüne ${ }^{24}$ tarih düşürdüğüne göre, şair, bu tarihte hayatta olmalıdır. Dolayısıyla Mustafa Zihnî’nin 1794 (1209)den 1797 (1212)ye kadar geçen üç yıl içerisinde ölmüş olduğu anlaşılmaktadır (Macit 2015: X).

Zihnî, Hazık Mehmet Efendi'yi kendisine üstat seçmiş, onun birçok şiirine nazireler yazmıştır. Şair, şiirlerinde aşk ve dini tasavvuf konularını işlemiştir. Divan, Zihnî’nin bilinen tek eseridir. 1761-1795 tarihleri arasında Erzurum'da bulunan valilere kasideler yazmış, devlet adamlarının tayinlerine, Erzurum'da inşa edilen eserlere tarihler düşmüş̧ür (Macit 2015: 2).

XVIII. yüzyılda, Erzurum ilim ve kültür hayatında yer alan diğer şahsiyetler ise: Fethullah Efendi, Eyyub Efendi, Kadızade Muhammed Efendi, Maksud Efendi, Lütfullah b. Muhammed Efendi, İbrahim el-Haravi Erzurumî, Seyyid Ahmet Efendi, Abdurrahim Rahmi ve Müderris Ömer Efendi’dir.

Fethullah Efendi, Şeyhülislam Feyzullah Efendi'nin oğludur. Doğum tarihi belli olmayan Fethullah Efendi, Anadolu Kazaskerliği ve bilahare Nakibü’l-Eşraflık yapmıştır. Mehmet Nusret'e göre, "paye-i meşihatı ihraz eyledikten sonra 1703 yılında İstanbul'da, idam edilmiştir.” (Mehmet Nusret 1338: 100).

Eyyub Efendi, 1658 y1lında Erzurum'da doğmuştur. Eğitimini memleketinde ikmal etmiş, bu arada hoca Habib Efendi'den tasavvuf okumuştur (Mehmet Nusret 1338: 106-107). Bir mürşidi kâmil bulmak amacıyla Şeyh İbrahim Hakkı'nın babasıyla birlikte yola çıkarak Tillo'ya gitmiştir. Burada Şeyh İsmail Fakirullah’a intisap etmiş (Kırkkılıç 2015: 10-11) ve onun emri üzerine tekrar Erzurum’a dönerek Aşağı Mumcu Mahallesindeki cami medresesinde ömrü boyunca irşad vazifesi ile meşgul olmuştur. 1722 yılında vefat etmiş, Erzincan Kapısı Mezarlığına defnolunmuştur (Mehmet Nusret 1338: 106-107).

\footnotetext{
${ }^{24}$ Bugün Erzurum ilinin Aşkale ilçesine bağl1 Büyükgeçit köyüdür.
} 
Kadızade Muhammed Efendi, Erzurum doğumlu olup, doğum tarihi malum değildir. Babası İspir Kadısı olduğundan, babasına nispetle kendisine "Kadızade" denilmiştir. Ayrıca “İspirî” diye de maruftur. İspir'de başladığı tahsilini Erzurum’da ikmal ettikten sonra İstanbul'a gitmiştir. O zamanın meşhur hocası olan "Kazabadî Hoca”nın derslerine devamla ikinci icazetini de ondan almıştır. Daha sonra Erzurum’a dönmüş, Sultaniye Medresesinde müderrislik yaparken Erzurum Müftülüğüne tayin edilmiştir (Mehmet Nusret 1338: 100-101). Bu görevi on beş sene yapan Kadızade, bu esnada 1725/1726 (1138) yılında bir de medrese yaptırmıştır. İspir'deki bu medresenin adı Kadığlu Medresesidir (Suluoğlu 2015: 32). Kendi el yazısıyla yazmış olduğu yirmi üç cilt eseri Birinci Dünya Savaşına kadar torunlarının kütüphanesinde muhafaza edilmiştir. En çok bilinen eserleri Ravzatü'l-Cennât Şerhi, Şerh-i Kelime-i Tevhid, Ahvâl-i Kabir Risâlesi, Sa'diyye Risâlesi, Bahru’l-Fetâvâ'dır (Uylaş 2006: 148-149; Ateş ve Yediyıldız 2007: 311). İbrahim Hakkı'yla çağdaş olan İspirî, 1759 yılında vefat etmiştir.

Maksud Efendi, tahsilini memleketinde tamamladıktan sonra Erzurum'a gelerek burada yerleşmiştir. Müddet-i ömrünü İbrahim Paşa Medresesi'nde tedrisle geçirmiş ve birçok talebe yetiştirmiştir (Mehmet Nusret 1338: 100).

Lütfullah b. Muhammed Efendi, Erzurum'da eğitimini tamamladıktan sonra İstanbul'a gitmiş ve az zamanda şöhret bulmuştur. Fatih Camisinde iki defa icazet vermiş, halka-i tedrisinden birçok âlim geçmiştir. 1787 yılında Halep’te vefat eden Lütfullah Efendi, büyük âlimlerden olup, “Göğsü gür” namıyla meşhurdur. Eserleri: “Mearicu’n-nur fi Şerhi Esma-i Hüsna”, “İhtisarü’l- Mevakif”, “El-Metalibü’l-Mev’ude ve’l-Mekasibü’l-Maksûde” ve “Râmuzu’t-Tahrir ve’t-Tefsir”dir (Mehmet Tahir 1333: 12).

İbrahim el-Haravî (Haddadî) ${ }^{25}$, Erzurumlu olup, “Yekdest”(tek elli) şöhretiyle bilinen bir âlimdir (Mehmet Tahir 1333: 242). Babasının adı Halil, dedesinin adı Bektaş’tır. Yazmış olduğu eserlerde “İbrahim b. Halil eş-Şehir bi'l-Haddadî” ve “İbrahim b. Halil b. Bektaş eş-Şehir bi’l-Haddadî” adlarını da kullanmıştır (Keleş 2016: 7). “Şemsü’l-Akâid”, “Nushu’l-Vâ’izin” ve “Reddü’l-Akyise ve Şerhuhu” adlı eserlerin sahibi olan Haravî, 1799 yılında vefat etmiştir (Mehmet Tahir 1333: 242). Haddâdî, yazdığı eserler ile diğer kitaplarını 1747 yılında kurulduğu söylenen Halil Efendi

\footnotetext{
25 İbrahim el-Haravî’nin adını Bursalı Mehmet Tahir, “İbrahim el-Haravî Erzurumı̂” şeklinde vermiştir (Mehmet Tahir 1333: 242). Ancak Reyhan Keleş, Erzurum’un yüzleri serisinde bunun adını "İbrahim elHaddâdî-i Erzurumî” olarak vermektedir (Keleş 2016: 7).
} 
Kütüphanesine vakfetmiştir. Ancak kitaplarının bir kısmını Lala Paşa Camisine vakfettiğine dair ilgili kayıtlar da mevcuttur (Keleş 2016: 7-8).

Seyyid Ahmet Efendi, Erzurumlu olup tahsilini tamamladıktan sonra Hatuniye Medresesinde müderrislik yapmıştır. Erzurum Müftülüğü de yapan Ahmet Efendi, 1717'de ölmüştür. Oğlu Ömer Efendi de Erzurum'un ilim ve kültür hayatına katkıda bulunmuştur (Konukçu 1992: 243).

Erzurum'da doğup tahsilini yine burada tamamlayan âlimlerden biri de Abdurrahim Rahmi'dir. Hakkında fazla bilgi olmayan Rahmi'nin babasının adı Mustafa'dır. Doğum tarihi belli değildir. Ancak Abdülkadir Erkal, Rahmi'nin müellif hatlı divanına düşmüş olduğu 1756(1170) tarihine dayanarak, onun 1722 ila 1732 (1135 ila 1145) yılları arasında doğmuş ve seksen yılı aşkın bir ömür sürmüş olabileceği tahmininde bulunmaktadır. Rahmi, küçüklüğünden itibaren iyi bir eğitim almıştır. Erzurum'da aldığı eğitim, onu İstanbul'daki medreselerin müderrisliğine kadar ulaştırmıştır. İstanbul'a gelişi 1776 (1190) yılı sonralarına rastlar. İstanbul'a gitmeden önce Erzurum'da bir yandan ilmi çalışmalarla uğraşırken, bir yanda da "Mecâmi'unNesâih", "Keşfü'l-Metâlib” gibi bazı önemli eserleri istinsah etmiştir. Şair de olan Rahmi’nin eserleri “Divan”, “İnşâ-i Mergûb”, “Refik-i Tarîk”, “Avâmil-i Âtîka”dır (Erkal 2015: 9-10). 1223/1808'de vefat etmiştir (Çınarcı 2007: 15). Medrese hocalığı ve mütercimlik gibi görevlerde bulunan Rahmi, Şeyhülislam Arif Hikmet Bey’in babasına da hocalık yapmıştır. Halk arasında "Hoca Rahmi" olarak ün salmıştır (Fatin Davud 2017: 172-173). Mevlana Kasım-1 Hani’nin “Seyr ü Sülûk İlel Mülkü’l-Mülûk” adlı risalesinin tercümesi olan Refik-i Tarîk, Rahmi’nin şair ve âlim kişiliğinin yanı sıra tasavvufi yönünün de olduğunu göstermektedir.

Doğum tarihi ve hayatı hakkında fazla tafsilat bulunmayan Müderris Ömer Efendi'nin tam adı Ömer b. Ali b. İbrahim b. Halil el-İspirî’ dir (Kehhale 1993: 566). Kaynaklarda daha ziyade "Ömer Faruk” olarak geçen Müderris Ömer Efendi, İspir'de dünyaya gelmiştir. Adındaki "İspir̂̂" nispetini de buradan almıştır (Kara 2015: 7). 1202/1788'de vefat eden Ömer Efendi, Fatih dersiamlarından olup, müderrislik ve Üsküdar naipliği de yapmıştır (Kehhale 1993: 566). Bir ara Amasya’ya giderek burada eğitim görmüşse de, daha sonra Erzurum'a dönmüş ve 1734 yılına kadar Erzurum'da ilmi çalışmalarını sürdürmüştür. 1735 tarihinde İstanbul'a gitmiş ve burada beş yıl Fatih Medresesinde tahsil gördükten sonra, Erzurum Yakutiye Medresesine tayin edilmiş ise de bu görevine başlamamıştır (Kara 2015: 8-12). Müderris Ömer Efendi çok yönlü ve 
birçok bilim dalında eserleri bulunan bir şahsiyettir. Tarih, fikıh, kelam, mantık, tefsir, tasavvuf ve Arap dili alanlarında olmak üzere otuz dört eseri mevcuttur.

\section{Sonuç}

Doğu ve kuzeyden Anadolu'ya uzanan yollar üzerinde bulunan Erzurum, bu özelliğinden dolayı ticaret, ilim ve kültür havzasının tam ortasında yer almaktadır. Bundan dolayı çeşitli milletler arasında el değiştirmiş, değişik kültür ve medeniyetlere ev sahipliği yapmış ve Anadolu'nun doğusunda dikkate değer ilim merkezlerinden biri olmuştur.

Müslüman Türklerin eline geçmeden önce Erzurum'a askeri ve ticari açıdan önem verilmiş, ancak şehrin ilmi ve kültürel yönü geride kalmıştır. Bölgedeki siyasi çekişmeler ve bunun sonucu oluşan istikrarsızlık, şehrin ilmi yönden gelişmesine engel olmuştur. İslami devirde bu çekişme ve istikrarsızlık devam etse de, Türk devletleri arasında ortak özellik olan din ve kültür birliği, Erzurum'da ilmi muhitin oluşmasına zemin hazırlamıştır.

İlmi ve kültürel kimliğini İslami devirde kazanan Erzurum'daki medrese ve camiler bunun canlı şahitleridir. Bu bakımdan Osmanlılara gelinceye kadar çok ciddi medreselerin kurulu olduğu şehir, önemli bir atılımı da İlhanlılar zamanında görmüştür. Şimdiye kadar yazılanların aksine, İlhanlılar dönemi Doğu Anadolu ve Erzurum bakımından oldukça ilerletici bir devirdir. Osmanlılar zamanı ise, bunların üzerine kurulmuş ve gelişmiş bir ilmi çevreyi gösterir.

Osmanlılar öncesi dönemde, Erzurum'da yetişmiş ilim adamları ve vücuda getirdikleri eserlerin önemli bir bölümü, Erzurum'un mücadele sahası olması ve sı sık saldırılara maruz kalması yüzünden günümüze kadar ulaşamamıştır. Diğer yandan yaşanan fetret dönemlerinde Erzurum'daki ilmi muhit hakkında detaylı bilgiye ulaşılamamaktadır. $\mathrm{Bu}$ durum şehirde kendini $\mathrm{XV}$. yüzyılda daha fazla hissettirmektedir. XVI. yüzyılda Osmanlı hâkimiyetine geçen Erzurum, AkkoyunluKarakoyunlu, Akkoyunlu- Safevi ve Safevi-Osmanlı rekabeti sırasında ilim ve kültür hayatı yönünden epeyce yara almıştır. Bu yaralarını Kanunî döneminde saran Erzurum, XVII. yüzyılda gerek şehirde yapılan ilim yuvalarıyla gerekse yetiştirdiği müderris, müftü, şair ve yazarlarıyla ilim ve kültür hayatı yönünden önemli bir gelişme göstermiştir. XVIII. yüzyıla gelindiğinde Erzurum, ilmi ve edebi ihtiyaçları karşılayacak ve teşvik edecek hale gelmiştir. Dolayısıyla ortaya çıkan zekâların İstanbul'a gitmelerine lüzum kalmamıştır. Erzurum, XVIII. yüzyılda, kültürel ve ilmi yönden 
geçen asırlara göre daha çok gelişme göstermiştir. Osmanlı Devleti'nde, söz sahibi olmuş şahsiyetler Erzurum'dan çıkmış ve yaşadıkları dönemde iz bırakmışlardır.

Özellikle belirtilmesi gereken bir husus; bahsedilen dönemlerde tasavvuf, halk ve ulema arasında çok etkili bir eğitim yoludur. Ancak, sözü edilen tasavvuf erbabının her biri "tasavvuftan geçinmemekte", yaptıkları işler (müderris, müftü, kadı vs.) dışında bir de tasavvuf ile hemhal olmaktadırlar. Herhalde o dönemlerden alınacak en önemli ders de budur.

\section{Kaynakça}

\section{Arşiv Belgeleri ve Kaynak Eserler}

Başbakanlık Osmanlı Arşivi (BOA), ML.MSF, V.

Başbakanlık Osmanlı Arşivi (BOA), Maliyede Müdevver Defter (MAD. d.) 299.

Başbakanlık Osmanlı Arşivi (BOA), Maliyede Müdevver Defter (MAD. d.) 4277.

Başbakanlık Osmanlı Arşivi (BOA), Maliyede Müdevver Defter (MAD. d.) 2929.

Başbakanlık Osmanlı Arşivi (BOA), Maliyede Müdevver Defter (MAD. d.) 6422.

BABİNGER, Franz (2000). Osmanlı Tarih Yazarları ve Eserleri, Çev: Coşkun Üçok, Ankara: Kültür Bakanlığı Yayınları.

BELÂZÛRÎ (1886). Futûhu’l-Buldân, Editör, M. J. De Goeje, Leiden: E.J. Brill.

CLAVIJO, Ruy Gonzales de (1928). Embassy to Tamerlane 1403-1406, İspanyolca'dan tercüme: G. Strange, London: Brodway House.

DAVUD, Fatîn (2017). Hâtimetü'l-Eş'âr (Fatin Tezkiresi), ekitap, Erişim Tarihi: 08.10.2018, (http://ekitap.kulturturizm.gov.tr/Eklenti/55976,fatin-tezkiresipdf.pdf?0), Haz. Ömer ÇİFTÇİ, Ankara: Kültür ve Turizm Bakanlı̆̆ı.

EVLIYYÂ ÇELEBİ, (1314). Evliya Çelebi Seyahatnamesi, Cilt II, nşr. A. CEVDET,

İstanbul: İkdâm Matbaas1.

İBN BATTUTA (2000). İbn Battuta Seyahatnamesi, Cilt 1, Çev. A. Sait Aykut, İstanbul: Yapı Kredi Yayınları. 
İBN HALLİKÂN (Tarihsiz). Vefeyâtu'l-A'yân ve Enbâu Ebnâi'z-Zemân, Cilt. I, nşr. İhsan Abbas, Beyrut: Dâru Sadir.

KLAVIYO (1975). Timur Devrinde Semerkand'a Seyahat, Terc. Ö. R. DOĞRUL, İstanbul: Nakışlar Yayınevi.

KEHHALE, Ömer Rıza (1993). Mu'cemu'l-Müellifin, Cilt. 2, Beyrut: Müessesetü’r-Risâle.

MEHMET NUSRET (1338). Tarihçe-i Erzurum yahut Hemşehrilere Armağan, İstanbul: Ali Şükrü Matbaası.

YÂKÛT El-HAMEVÎ (1993). Mu'cemu'l-Udebâ', Cilt. II, nşr. İhsan Abbas, Beyrut: Dâru'l-Garbu'l-İslâmî.

\section{Kitap, Makale vd.}

AKKUŞ, Metin (2015). Erzurum'un Yüzleri Nef'i, Erzurum: Atatürk Üniversitesi Yayınları.

AKKUŞ, Metin (1991). Nef'i Sanatı ve Türkçe Divanı (İnceleme-Karşılaştırmalı Metin), Basılmamış Doktora Tezi, Erzurum.

ALTINTAŞ, Hayrani (1997). Erzurumlu İbrahim Hakkl, İstanbul: Milli Eğitim Bakanlığı Yayınları.

ATEŞ, Nilüfer ve YEDIYYILDIZ, Asım (2007). “Erzurumlu Kadızâde Efendi’nin Vasiyetnamesine Tahlili Bir Bakış", Uludă̆ Üniversitesi Illahiyat Fakültesi Dergisi, Cilt 16, Sayı: 2, (309-326).

AYDIN, Dündar (1998). Erzurum Beylerbeyliği ve Teşkilatı; Kuruluş ve Genişleme Devri (1535-1566), Ankara: Türk Tarih Kurumu.

AYDIN, Dündar (1970). “Erzurum Şehri’nin Osmanlı Fethini Müteakip Yeniden İmarı, İskânı ve İlk Sakinleri”, $A \ddot{E E F A D, ~ I / 1, ~ s s . ~ 45-56, ~ E r z u r u m . ~}$

BAŞAR, Zeki (1998). Cumhuriyet Dönemi Erzurumlu 54 Müellif ve Eserleri, İstanbul: Yy.

BAŞAR, Zeki (1972). İçtimai Adetlerimiz-İnançlarımız ve Erzurum İlindeki Ziyaret Yerlerimiz, Ankara: Atatürk Üniversitesi Yayınları.

BEYGU, Abdurrahim Şerif (1936). Erzurum Tarihi Anttlarl, Kitabeleri, İstanbul: Bozkurt Basımevi. 
BİLMEN, Ömer Nasuhi (1327). “Mehmet Hazık Efendi”, Beyanü’l-Hak, Cilt 4, ss. $1929-1930$.

BURSALI, Mehmet Tahir (1333). Osmanlı Müellifleri, Cilt I-II, İstanbul: Matbaa-i Amire.

BURSALI, Mehmet Tahir (1342). Osmanlı Müellifleri, Cilt III, İstanbul: Matbaa-i Amire.

ÇELIKK, Muammer (1997). Erzurum Kitabı, İstanbul: Erzurum Kitaplığı.

ÇINARCI, M. Nuri (2007). Şeyhülislam Arif Hikmet Bey'in Tezkiretü'ş Şu'ârâsı ve Transkripsiyonlu Metni, Gaziantep Üniversitesi Sosyal Bilimler Enstitüsü, Basılmamış Yüksek Lisans Tezi, Gaziantep.

ÇÖĞENLİ, Sadi ve KARA, Ömer (2015). Erzurum'un Yüzleri Şeyhülislam Feyzullah Efendi, Erzurum: Atatürk Üniversitesi Yayınları.

ERKAL, Abdülkadir (2015). Erzurum’un Yüzleri Abdurrahim Rahmi, Erzurum: Atatürk Üniversitesi Yayınları.

ERKAN, Mustafa (1994). “Darir”, Türkiye Diyanet Vakfi (TDV) İslam Ansiklopedisi, Cilt 8, İstanbul: Türkiye Diyanet Vakfı Yayınları.

FINDIKOĞLU, Ziyaettin Fahri (1927). Erzurum Şairleri, İstanbul: Sanayi-i Nefise Matbaasi.

GÜFTA, Hüseyin (2014). Erzurum'un Yüzleri Hazlk, Erzurum: Atatürk Üniversitesi Yayınları.

GÜFTA, Hüseyin (1992). Hazık Mehmet Efendi'nin Hayatı, Edebi Şahsiyeti, Eserleri ve Divanının Tenkidli Metni, Atatürk Üniversitesi Sosyal Bilimler Enstitüsü Türk Dili ve Edebiyatı Anabilim Dalı, Basılmamış Yüksek Lisans Tezi, Erzurum.

GÜLSOY, Ersin (2000). “Girit Seferleri, Gazavâtnâmeleri ve Özellikleri”, Yeni Türkiye Dergisi, Osmanlı Özel Sayısı III, Yı1: 6, Sayı: 33, Mayıs-Haziran, ss. 640-642.

İBRAHIMHAKKIOĞLU, Uğur (1998). Erzurumlu İbrahim Hakkı ve İki Torunu Feyyaz Efendi ile Zakir Bey, Ankara: Adalet Matbaacıl1k.

İPŞİRLİ, Mehmet (1994). "Duâgû”, Türkiye Diyanet Vakfi (TDV) İslam Ansiklopedisi, Cilt 9, İstanbul: Türkiye Diyanet Vakfı Yayınları. 
KARA, Ömer (2015). Erzurum'un Yüzleri Müderris Ömer Efendi, Erzurum: Atatürk Üniversitesi Yayınları.

KARAHAN, Abdülkadir (1986). Nef'i, Ankara: Kültür ve Turizm Bakanlığı Yayınları.

KARAHAN, Abdülkadir (1992). Nef'i Divanı'ndan Seçmeler, Ankara: Kültür Bakanlığı Yayınları.

KARAHAN, Leyla (1995). Erzurumlu Darir, İstanbul: MEB Yayınları.

KARAMAĞARALI, Haluk (1971). “Erzurum’daki Hatuniye Medresesi’nin Tarihi ve Banisi Hakkında Mülahazalar”, Selçuklu Araştırmaları Dergisi, III, 209-247, Ankara.

KASIR, Hasan Ali (1999). Erzurum Şairleri, İstanbul: Dergah Yayınları.

KELEŞ, Reyhan (2016). Erzurum'un Yüzleri İbrahim el Haddâdî, Erzurum: Atatürk Üniversitesi Yayınları.

KILIÇ, Ümit (2009). “Erzurum'da Cafer Efendi Vakfi”, Atatürk Üniversitesi Türkiyat Araştırmaları Enstitüsü Dergisi, Sayı 41, Erzurum, (173-187).

KIRKKILIÇ, Ahmet (2015). Erzurum'un Yüzleri Ibrahim Hakkı Hazretleri, Erzurum: Atatürk Üniversitesi Yayınları.

KONUKÇU, Enver (1992). Selçuklulardan Cumhuriyete Erzurum, Ankara: Erzurum Ticaret ve Sanayi Odası Yardım, Araştırma ve Geliştirme Vakfı.

KONUKÇU, Enver (1989). “Tarihte Erzurum”, Şehr-i Mübarek Erzurum, ss. 1137, Ankara: Erzurum Belediyesi Kültür Yayınları.

KONYALI, İbrahim Hakkı (1960). Abideleri ve Kitabeleri ile Erzurum Tarihi, İstanbul: Erzurum Tarihini Araştırma ve Tanıtma Derneği Yayınları.

KÖKTEKİN, Kazım (2015). Erzurum'un Yüzleri Kadı Darir, Erzurum: Atatürk Üniversitesi Yayınları.

KÖPRÜLÜ, Orhan Fuad (1997). "Feyzullah Efendi”, İslâm Ansiklopedisi, Cilt 4, ss. 593-600, Eskişehir: MEB Yayınları.

KÜÇÜKUĞURLU, Murat ve ÇELİK, Şemsettin (2013). Erzurum Kalesi, İstanbul: Erzurum Büyükşehir Belediyesi Kültür Yayınları. 
KÜÇÜKUĞURLU, Murat (2018). Erzurum Çarşı Pazar, Konya: Çizgi Kitabevi Yayınları.

MACİT, Muhsin (2015). Erzurum’un Yüzleri Zihni, Erzurum: Atatürk Üniversitesi Yayınları.

MACİT, Muhsin (1996). Erzurumlu Zihnî Divanı (İnceleme-Metin), Erzurum: Atatürk Üniversitesi Yayınları.

NECİB ASIM (1327). “Osmanlı Tarihi Nüvisleri ve Müverrihleri”, Tarih-i Osman-i Encümeni Mecmuası, Say1: 8 (1 Haziran 1327), ss. 498-499, İstanbul.

OKÇU, Naci Sami ve KARABEY, Turgut (1989). "Erzurumlu Şair, Yazar, İlim Adamları ve sanatkârlar”, Şehr-i Mübarek Erzurum, ss. 396-423, Ankara: Erzurum Belediyesi Yayınları.

ÖZCAN, Abdülkadir (1993). “Cevâhirü’t-Tevârih”, Türkiye Diyanet Vakfı (TDV) İslam Ansiklopedisi, Cilt 7, İstanbul: Türkiye Diyanet Vakfı Yayınları.

ÖZCAN, Özgen (2013). Pious Endowments nd Land In The Seventeenth Century Ottoman Empire: The Vakf of Şeyhülislam Feyzullah Efendi, Graduate School of Economics and Social Sciences of İhsan Doğramacı Bilkent Üniversitesi, Basılmamış Yüksek Lisans Tezi, Ankara.

SERTOĞLU, Mithat (1968). "XVI. Yüzy1lda Erzurum”, Belgelerle Türk Tarihi Dergisi, Say1: 8, (Mayıs 1968), ss. 76-80, İstanbul, Menteş Kitabevi.

SULUOĞLU, Muhammed Hanefi (2015). Erzurum’un Yüzleri Kadızade Mehmet Arif Efendi, Erzurum: Atatürk Üniversitesi Yayınları.

SÜMER, Faruk (1990). Selçuklular Devrinde Doğu Anadolu'da Türk Beylikleri, Ankara: Türk Tarih Kurumu.

TAYŞİ, Mehmet Serhan (1995). "Feyzullah Efendi”, Türkiye Diyanet Vakf (TDV) Íslam Ansiklopedisi, Cilt 12, İstanbul: Türkiye Diyanet Vakfı Yayınları.

TURAN, Osman (1993). Doğu Anadolu Türk Devletleri Tarihi, İstanbul: Boğaziçi Yayınları.

UYLAŞ, Sait (2006). “Erzurumlu Kadızade Mehmet Efendi’nin Kur'ân'a Dair Bir Risalesi”, Nüsha, Y11. VI, Sayı: 23, Güz, (147-155).

UYLAŞ, Sait (2015). Erzurum’un Yüzleri Ebû 'Alî el-Kâlî, Erzurum: Atatürk Üniversitesi Yayınları. 
UZUNÇARŞILI, İsmail Hakkı (1988). Osmanlı Devletinin Ilmiye Teşkilatı, Ankara: Türk Tarih Kurumu Basımevi.

UZUNÇARŞILI, İsmail Hakkı (1995). Osmanlı Tarihi, Cilt 4, Kısım 1, Ankara: Türk Tarih Kurumu Basımevi.

WOODHEAD, Christine (2000). “İbrahim Mülhemi”, Türkiye Diyanet Vakf (TDV) İslam Ansiklopedisi, Cilt 21, İstanbul: Türkiye Diyanet Vakfı Yayınları.

YILDIRIM, Sefa ve KILIÇ, Ümit (2018). “Klasik Dönem Osmanlı Devleti’nde Eğitim ve Öğretim”, Atatürk Üniversitesi Sosyal Bilimler Enstitüsü Dergisi, Nisan 2018, 22(Özel Say1): (603-627).

YINANÇ, Mükrimin Halil (1997). “Erzurum”, İslâm Ansiklopedisi, Cilt 4, ss. 345-353, Eskişehir: MEB Yayınları.

Emekli Imam Hacı Selahattin Hoca (Çelik)den derlenmiştir. Baba adı: Yusuf, Ana adı: Mihriban, Doğum yeri ve tarihi: Erzurum/Narman - 1933, Derleme tarihi: 22.02.2017. 